THE MEANING OF SOCIAL CAPITAL AND ITS LINK TO COLLECTIVE ACTION

by

Elinor Ostrom and T. K. Ahn

(C) 2007 by authors

Forthcoming 2008 in Handbook on Social Capital, ed. Gert T. Svendsen and Gunnar L. Svendsen. Northampton, MA: Edward Elgar.

Workshop in Political Theory and Policy Analysis

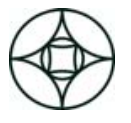

Indiana University, 513 North Park, Bloomington, IN 47408-3895 USA phone: 812-855-0441 • fax: 812-855-3150

workshop@indiana.edu •http://www.indiana.edu/ workshop 


\title{
The Meaning of Social Capital and Its Link to Collective Action
}

by

\author{
Elinor Ostrom and T. K. Ahn
}

\section{The rapid growth of social capital literature}

Few social scientific concepts have gathered so much attention and so many followers in such a short period of time than the concept of social capital. The fundamental idea can be traced back at least to Tocqueville ([1840] 1945), Hanifan (1920), Jacobs (1961), and Loury (1977). Bourdieu (1986) used the term “social capital” to express ideas that foretold the current meaning of the term. Schultz (1961) and Becker (1962, 1964), among other economists, articulated theories of "human” capital in the 1960s, paving the way to a broader understanding of "capital.”

It was only toward the end of the last century, however, that James Coleman (1988) carried out the first systematic conceptualization of the concept of social capital. Social capital has slowly gained recognition, and important theoretical developments have been made (for example, see Burt 1992). The publication of Robert Putnam and colleagues’ celebrated book, Making Democracy Work, in 1993 unleashed social capital research into its current widespread and lively phase of development. The growth of interest in this subject is reflected in Table 1 . The number of citations to articles and books overtly using the concept of social capital has escalated from two citations in 1991 to 443 citations in 2006.

(Table 1 about here)

Now, we encounter "social capital” in every corner of the social sciences, and researchers are tackling a wide variety of questions including: the relationship between personal networks and political participation (Lake and Huckfeldt 1998), the 
challenge of building effective developmental policies (Gibson et al. 2005), the difference in the industrial structures of the capitalist economies (Fukuyama 1995), the poor performance of the African economies (Collier and Gunning 1999), the health and satisfaction of citizens (Kawachi et al. 1997), and the impact of active team-sport programs to offset the higher potential for student disturbances in large urban schools (Langbein and Bess 2002).

The reason for this rapid growth of the social capital literature lies in part in the limits of the "standard" approaches to the problems of economic development and political order. Abundant anomalies have accumulated that call for careful examination of the factors that were left out of earlier theories. The differential political and economic performance across nations and communities, for example, could not be answered satisfactorily without seriously studying the omitted factors: trust and norms of reciprocity, networks and forms of civic engagement, and both formal and informal institutions.

The social capital approach takes these factors seriously as causes of behavior and collective social outcomes. The social capital approach does this in ways that are consistent with continued and lively development of neoclassical economics and rational choice approaches. In sum, the social capital approach improves the knowledge of macro political and economic phenomena by expanding the factors to be incorporated in such knowledge and by constructing richer causality among those factors, and by achieving these without dismissing the insights from neoclassical economics and rational choice theories.

Abundant, and often valid, criticisms of the concept have also levied against it (Arrow 1999; Solow 1999; Fine 2001; Durlauf 2002-to name a few). Solow notes that much of the social capital research is plagued by "vague ideas" and "casual 
empiricism.” Academic research can be afflicted by fads and fashions just as much as any other field. We believe, however, that the concept of social capital can be defined carefully. It is a useful concept that should take its place alongside physical and human capital as core concepts of great usefulness to the social sciences.

\section{Social capital and the second-generation theories of collective action}

Collective-action theories_especially with their lively development into behavioral, evolutionary, and indirect evolutionary versions—-will, and should, provide further analytical foundations for future social capital research. The economic and political performances of societies, from villages to international communities, depend critically on how the members of a community solve the problem of collective action. Contemporary theorists of social capital, almost without exception, open their discourse by placing the problem of collective action at the center of economic and political problems. The linkage of collective-action theories and the social capital approach is, however, at best, incomplete up to now. Social capital researchers use the collective-action paradigm primarily to frame their research problems. Incorporating forms of social capital, such as trustworthiness, networks, and institutions, into a collective-action framework is a frequent approach in narratives, but is less frequent in analytically rigorous formal models. ${ }^{1}$

A fundamental limitation exists for the first-generation collective-action models, however, because many assume homogeneous, selfish individuals. The meanings of trust and norms either cannot be properly understood, or may only be captured to a limited extent, from the perspective of the first-generation collectiveaction models. Second-generation theories of collective action are informed by decades of experimental studies influenced by behavioral and evolutionary game- 
theoretic models. This section discusses how the forms of social capital, their particular configurations, and their interaction with other factors facilitate collective action from the perspective of a fledging second-generation collective-action theory (see E. Ostrom 1998, 2005). ${ }^{2}$

\section{What is social capital?}

Let us clarify our own definition of social capital. All forms of capital involve the creation of assets by allocating resources that could be used up in immediate consumption to create assets that generate a potential flow of benefits over a future time horizon. Capital in its most basic sense is a set of assets capable of generating future benefits for at least some individuals (Lachmann 1978). The set of individuals involved may be relatively small, such as a family or a work team, or quite large, such as the participants in an economy or a political system. The flow of benefits generated by capital may all be positive or a smaller group may be benefited while a larger group is harmed. The latter can occur when social capital is used to facilitate collusion among a smaller group leading to high benefits for those involved and generating negative externalities for others. This dark side of social capital can involve police gaining trust in each other to collude so as not to report excessive force used by another police officer (Langbein and Jorstad 2002), corporations or nations colluding with one another to create cartels (Hoffman and Libecap 1995), or members of the Mafia colluding to undertake illegal, economic activities (Gambetta 1988).

Capital always involves multiple forms. Examples of physical capital include roads, irrigation systems, schools, factories, and the machinery inside factories. Human capital includes many kinds of different forms of knowledge and personal skills (Schultz 1961). For some purposes, scholars can reasonably attach a value to a 
particular form of physical or human capital—a factory or a college degree. To do so requires substantial knowledge about the date of acquisition, the specific sector, the amount of maintenance invested over time, and the future demands for this particular type of capital. With even more assumptions, one can measure aggregations - the industrial capital of a nation or its educational achievement. Whether the assigned aggregate value of a particular form of capital is meaningful depends on the question being asked, the detailed type of information contained in the estimate, and the accounting formulas being used.

Given the diversity of forms of physical and human capital, it is not surprising that multiple forms of social capital exist. We have selected three types of social capital that are particularly important in the study of collective action: (1) trustworthiness, (2) networks, and (3) formal and informal rules or institutions. We view social capital as an attribute of individuals and of their relationships that enhance their ability to solve collective-action problems. The relevant forms of social capital and their specific roles need to be provided by the theoretical framework in which the concept is located. We regard second-generation collective-action theories as the organizing tool for social capital discourse. Therefore, this section provides a brief discussion of second-generation theories of collective action.

\section{Second-generation collective-action theories}

Theories of collective action concern settings in which there is a group of individuals, a common interest among them, and potential conflict between the common interest and each individual's interest. Collective-action problems arise whenever individuals face alternative courses of actions between short-term self-regarding choices and one that, if followed by a large enough number of individuals in a group, benefits all. The problem is one of overcoming selfish incentives and achieving mutually beneficial 
cooperative ways of getting things done. Solving the dilemma of collective action is not easy; whatever others do, an individual is always better off in the short-run by choosing not to cooperate with others. The Prisoner's Dilemma game characterizes the situation succinctly. It has been considered the central problem of political science (E. Ostrom 1998).

The first generation of collective-action theories (Olson 1965; G. Hardin 1968) concluded that individuals could not achieve joint benefits when left by themselves. The ways of overcoming the supposed inability of individuals to solve these problems included regulation by an external authority, provision of selective incentives, or privatization. The first-generation collective-action theories were a valid criticism of the naive belief that individuals with common interests would voluntarily act to achieve those common interests, expressed by earlier group theorists such as Bentley (1949) and Truman (1958). Research on collective action has shown that the first-generation theories, while not entirely wrong, represent only the limiting case of the ways that collective-action situations are structured and how individuals cope with them (Blomquist 1992; Bolton and Ockenfels 2000; NRC 2002—to name just a few relevant studies).

At the core of the first-generation theories of collective action is an image of atomized, selfish, and fully rational individuals. In the field, individuals do not live in an atomized world. Many collective-action problems are embedded in pre-existing networks, organizations, or other ongoing relationships among individuals. Second, the universal selfishness assumption has been repeatedly rejected by empirical research conducted in the field and the experimental laboratory (see Camerer 2003). Individuals do exist, who are concerned only with their own immediate material gains, but a significant proportion of individuals do have nonselfish utility functions 
(Frey 1994, 1997). Further, nonselfish individuals also differ among themselves in terms of the extent to which they presuppose universal selfishness. Second-generation collective-action theories acknowledge the existence of multiple types of individuals as a core principle of modeling (E. Ostrom 2005). In addition to the standard noncooperative game theory that has been the key modeling tool of the firstgeneration collective-action theories, second-generation theories also use behavioral and evolutionary game theories (Gintis 2000; Henrich 2004). Many models of collective action based on behavioral or evolutionary game theories still use the solution concepts of the standard noncooperative game theory to address new kinds of questions that are particularly relevant to social capital research. For example, one of the main concerns of behavioral game theory is the problem of social motivations (Rabin 1993; Fehr and Schmidt 1999; Bolton and Ockenfels 2000; Charness and Rabin 2002), which has a direct implication to the discussion of trust and trustworthiness in social capital research. Another example is the problem of endogenous preferences, a key issue in the evolutionary game-theoretic approach to collective action (Bowles 1998, 2000; Güth and Yaari 1992; Güth and Kliemt 1998; Güth, Kliemt, and Peleg 2000), that provides a way to model the historical interaction between the institutional structures and the quality of citizenship described by Putnam et al. (1993).

\section{Forms of social capital, trust, and collective action}

In this section, we present our views on the forms of social capital, how they enhance trust among people and, thus, breed cooperation a collective-action situation. We emphasize two points. First, social capital is a rubric. What is fundamental is how collective action is achieved. Various aspects of collective action can be studied without resorting to the concept of social capital, but in some contexts, the concept of 
social capital helps to unravel puzzles. Social capital provides a synthesizing approach to how cultural, social, and institutional aspects of communities of various sizes jointly affect their capacity of dealing with collective-action problems.

Second, the ideas fundamental to a social capital approach cannot be entirely captured by the first-generation collective-action theories that tend to reduce trust, trustworthiness, and norms to incentives embedded in social structures of interaction. It is essential to couple social capital to the second-generation theories of collective action that regard heterogeneous preferences seriously. What is important is to recognize genuine trustworthiness, defined in terms of preferences that are consistent with conditional cooperation, as independent and nonreducible reasons why some communities achieve collective action while others fail. Many social capital researchers are not conscious, let alone explicit, about the underlying version of collective-action theories on which their discussions of social capital and trust are built.

\section{Trust as linkage between the forms of social capital and collective action}

The various forms of social capital contribute to successful collective action, almost always, by enhancing trust among the actors. In other words, trust is the core link between social capital and collective action. Trust is enhanced when individuals are trustworthy, are networked with one another, and are within institutions that reward honest behavior. These relationships are shown in Figure 1.

(Figure 1 about here)

We agree with Torsvik (2000) that trust itself is not a form of social capital but an outcome of the forms of social capital linking them to successful collective action. The existence of trust among a group of individuals can often be explained as a result 
of the other forms of social capital such as trustworthiness of people, networks, and institutions.

Drawing on Gambetta (2000), we define trust as "a particular level of the subjective probability with which an agent assesses that another agent or group of agents will perform a particular action.” Thus, trust allows the trustor to take an action involving risk of loss if the trustee does not perform the reciprocating action (E. Ostrom and Walker 2003). Another crucial aspect of trust is that it involves an opportunity for both the trustor and the trustee to enhance their welfare.

Let us think of a business transaction in which agent A has to pay before agent B delivers the desired good. If A pays the price and B delivers the good, both are better off than in the absence of the transaction. B might be tempted not to deliver the good even after A has paid the price. This lack of trustworthiness would leave agent A with a net loss. If A does not trust B in the first place and refuses to complete the transaction, B will have lost an opportunity to sell their product and thus increase their wealth. Thus, trust and trustworthiness are essential for the completion of many complex transactions in modern life. As Kenneth Arrow (1972, p. 357), pointed out: "Virtually every commercial transaction has within itself an element of trust, certainly any transaction conducted over a period of time. It can be plausibly argued that much of economic backwardness in the world can be explained by a lack of mutual confidence.”

Theoretically, the subjective belief of a trustor can be independent of objective conditions. One can falsely trust someone who is not trustworthy and experience losses. It is quite reasonable, however, to assume that trust as a subjective belief cannot be sustained in the long run unless it is verified frequently enough by the behavior of the trusted (Yamagishi 2001; Yamagishi et al. 1999). When trust is 
defined as a subjective belief about a trustee’s unobservable or not-yet-observed behavior, it is possible that an untrustworthy individual trusts another agent. Saying that A, who wouldn't repay what he borrowed from B, however, trusts B to repay what B might borrow from A, is highly unlikely. ${ }^{3}$

The variants of the Prisoner's Dilemma game in standard noncooperative game theory provide ample examples where the expectations of others' behavior in collective-action situations can be reduced to other factors. Repetitive interaction among individuals—a sign of a robust network and an important form of social capital—provides incentives to individuals to build a reputation of being trustworthy. Even very selfish individuals may not betray the trustor under those circumstances. In fact, precisely because he is selfish and he wishes to obtain gains from future transactions with the trustor, a selfish individual embedded in assured repetitive interactions will be more likely to reciprocate trust.

Dense horizontal networks—referred to as bonding social capital—with the capability of efficiently transmitting information across the network members also create incentives to behave in a trustworthy manner even for those who have only selfish motivations (see discussion in Svendsen and Svendsen 2004 and this volume). Suppose that, though the transaction between A and B is not of a repetitive nature, there are other agents $\mathrm{C}$ and $\mathrm{D}$ who obtain information about the transaction and condition their future transactions with A on whether A behaves trustworthily in their transaction with $\mathrm{B}$. Then again, A has an incentive not to betray B, not because of the prospects for future gain from transactions with $\mathrm{B}$, but in expectation of those from $\mathrm{C}$ and D. Anirudh Krishna (2002) and Mark Baker (2005) provide carefully researched studies of local communities in India and how bonding social capital enables local residents to engage in challenging forms of collective action-establishing new 
investments in development activities and coping effectively with landslides and other environmental threats.

The possibility of sustaining cooperation via reputation in widespread networks connecting individuals who do not live in the same community and cannot establish close face-to-face networks_-bridging social capital—has sparked interest in medieval guilds (Greif et al. 1994), law merchants (Milgrom et al. 1990), international trade associations (Maggi 1999), and eBay’s feedback system (Janssen 2006; Malaga 2001; Resnick et al. 2006; Standifird 2001). Krishna (2002) and Baker (2005) also document that many successful local communities in India rely on both close bonding forms of social capital as well as bridging forms. By linking the close relationships within a local community to external actors who have new knowledge, larger stores of financial capital, and political connections, communities characterized by both bonding and bridging capital are more effective in solving big problems than those who have only close networks or loose connections to the outside world. Granovetter (1973) illustrated the power of weak ties long before the term "bridging” social capital was coined.

Institutional rules also create incentives for the parties of transactions to behave trustworthily. They can influence behavior directly by establishing mechanisms of rewards and punishment or indirectly to help individuals govern themselves by providing information, technical advice, alternative conflict-resolution mechanisms, and so forth. When effective formal or informal rules-in-use exist that specify punishments to be imposed on those who do not keep contracts, they affect a trustor's assessment of the trustee’s future behavior. Intentionally not delivering the goods after receiving the payment for them constitutes a crime. The quality of a rule- 
in-use, or a statute as a form of social capital, depends not only on content but more critically on how they are actually implemented (Freitag 2006).

We have so far examined how networks and institutions enhance trust among individuals in a collective-action situation. In sum, they change the incentive structure of the trustee. As a result, the trustor knows the incentive structure the trustee faces given the repetitive nature of the interaction, the existence of other network members who observe the trustee's behavior, and the rules and laws that punish or reward the trustee. Common understanding between the trustor and trustee regarding the existence and functioning of those factors encourages them both to engage in productive transactions.

\section{Trustworthiness as a form of social capital}

Trust cannot always be explained entirely by the incentives embedded in the structure of social interactions. The trustworthiness of trustees often results from the characteristics of the trustees themselves. Imagine a transaction that occurs in absolute absence of other forms of social capital: no repetition, no networks, and no possibility of external sanctions. An example is a local villager being asked for help by a lost traveler who promises some reward in the future. Another example is a first mover in a single-play sequential prisoner's dilemma experiment conducted in a double-blind procedure. Both face a decision whether or not to trust the other's pure motivation. In those cases, the probability assessments by the trustors depend only on their belief regarding the trustees’ motivation. Having neither any specific information about the trustee's trustworthiness nor the structural incentives the trustee faces, a trustor regards the trustee as representing a population of heterogeneous individuals. The individual who wants to be trusted in these cases is represented as coming from a 
population in the trustor's mind. The distribution of trustworthy individuals in this hypothetical population is based on the trustee's observable characteristics (if these can, indeed, be observed), such as appearance, dress, gender, age, language, and so forth (see Frey and Bohnet 1996).

The above examples are presented to abstract a trustor's belief about a trustee's motivation as an independent source of the trustor's expectation of the trustee’s behavior. We emphasize that individuals' intrinsic values are an independent reason for behaving cooperatively and reserve the term trustworthiness primarily to refer to such nonselfish motives. In the language of game theory, trustworthiness refers to the characteristics of the trustee's preference. As numerous one-shot experiments using prisoner's dilemma type monetary payoff structures have shown (see, for example, Ahn et al. 2003), a significant number of individuals in the trustee's position do choose to reciprocate. At the same time, not all do. The fact that the magnitude of the gains from exploitation matters (Ahn et al. 2001; Clark and Sefton 2001) indicates that individuals are distributed on a continuous scale of trustworthiness. In other words, the size of the internal parameter that the individual assigns to behaving in a trustworthy manner varies across individuals (Crawford and Ostrom 2005). Behavioral game theorists (Fehr and Schmidt 1999; Bolton and Ockenfels 2000) have developed formal models to reflect such motivational heterogeneity.

Unless trustworthiness as preference is recognized as an independent reason for behaving cooperatively, the concept of generalized trust loses meaning. Generalized trust, borrowing Yamagishi’s (2001, p. 143) definition, is a baseline expectation of others' trustworthiness. ${ }^{4}$ We add, not necessarily reflecting Yamagishi's view, that the generalized trust reflects the average level of 
trustworthiness in a society. If trustworthiness is primarily an effect of networks and ongoing relationships, as Russell Hardin (2002) argues, it truly is difficult to conceive of "general” trust or "average” level of trustworthiness. Then again, social capital itself is more or less irrelevant beyond the confines of a network. But if one acknowledges that among multiple communities of a comparable size, from villages to nations, the average trustworthiness of people may differ and it affects the way collective-action problems are solved across communities, the concept of general trust and the underlying general trustworthiness become quite meaningful. Social capital can then become a useful rubric to refer to them along with other cooperationenhancing factors for a society.

The potential of modern market economies and democratic political orders makes it imperative for individuals to deal with others beyond the confines of intimate relations and close networks. The very condition for a successful market economy and democracy is that a vast number of people relate in a trustworthy manner when dealing with others - many of whom do not know one another and cannot incorporate repeated interaction or a network - to achieve collective actions of various scales. Many of these relationships can properly be characterized as a single-shot situation, or one that is repeated a very small number of times. The establishment and maintenance of such social relationships depend on the trustworthiness of people that cannot be explained away by the incentives provided by the structure.

The trustworthiness of a population can be formalized in game theory by introducing a generic utility function that contains a "type” parameter (Crawford and Ostrom 2005). Suppose the parameter takes a value of 0 for purely selfish individuals, whose cooperative behavior can only be induced by other forms of social capital, and a value of 1 for those who are entirely trustworthy, who would behave cooperatively 
in the absolute absence of other cooperation-enhancing social capital. Then, the statistics of the parameter, its mean value and variance, and so forth, is an independent input to the trustor's probability assessment when faced with an anonymous individual or individuals in a collective-action situation. The evidence suggests that few individuals are truly unconditional altruists who cooperate or trust others no matter what! Rather, in addition to networks and institutions, considerations of equity and fairness also affect the likelihood of individuals adopting conditional cooperation in collective-action situations (Ahn et al. 2003; Bolton and Ockenfels 2000; Fehr and Schmidt 1999).

Reciprocity is an internalized personal moral norm as well as a pattern of social exchange. E. Ostrom (1998, p. 10) defines reciprocity as involving a family of strategies in collective-action situations including “(1) an effort to identify who else is involved, (2) an assessment of the likelihood that others are conditional cooperators, (3) a decision to cooperate initially with others if others are trusted to be conditional cooperators, (4) a refusal to cooperate with those who do not reciprocate, and (5) punishment of those who betray trust.”

As the above definition indicates, trust and trustworthiness are integral elements of reciprocity. An individual who abides by the norm of reciprocity is trustworthy. The information about others' trustworthiness is an essential input to a reciprocal individual's decision whether or not to cooperate. That the norm of reciprocity prevails in a society implies that a significant proportion of individuals in the society are trustworthy.

Reciprocity as a prevailing pattern of interaction among individuals is, in game-theoretic terms, an efficient equilibrium of repeated social dilemma games with multiple types of individuals and incomplete information. For reciprocity to prevail as 
patterns of social interaction, trustworthy individuals need not only to overcome the temptation to free-ride but they also need to coordinate their actions successfully.

\section{Networks}

As Putnam and colleagues (1993) point out, dense networks of social exchange are a crucial condition for the rise of the norm of generalized reciprocity. When trustworthy individuals who are willing to cooperate with others constitute only a small minority of a society's whole population, one condition for them to survive, prosper, and spread is to establish a network among them. Evolutionary theorists (Trivers 1971; Richerson and Boyd 2005; Axelrod 1981, 1984; Heiner 2002) have shown that when reciprocal agents using conditionally cooperative strategies have a higher chance to interact with one another than with the surrounding population in general, they can invade a population composed of agents who always defect. Information regarding a potential transaction partner's trustworthiness is crucial when trustworthy individuals try to initiate cooperation (Ahn et al. 2007). Dense social networks also encourage the development of reciprocity norms through the transmission of information across individuals about who is trustworthy and who is not.

\section{Institutions-formal and informal rules as a form of social capital}

We define institutions in broad terms as prescriptions that specify what actions (or outcomes) are required, prohibited, or permitted, and the sanctions authorized if the rules are not followed (Crawford and Ostrom 2005; E. Ostrom et al. 1994, p. 38). Institutions are thus the rules of a game that people devise (North 1990). Rules are the results of human beings' efforts to establish order and increase predictability of social outcomes. Rules can be used to increase the welfare of many individuals or, if 
collective-choice processes are controlled by a well-organized subgroup, to benefit that group more than others. ${ }^{5}$

Written laws, administrative regulations, court decisions, and so forth are formal rules written on paper and enforced by public authority. Grootaert (1998) considers the view of social capital that encompasses formalized institutional structures (including governments, political regimes, court systems, as well as civil and political liberties). Many scholars (for example, Fuller 1981; Taylor 1982) have argued that legal rules and formal institutions are an ineffective means to solve collective-action problems, and sometimes might even undermine the very basis of social cooperation. This view is a valid criticism to Hobbesian tradition in which the state is regarded as the inevitable and omnipotent solution to the collective-action problem (see V. Ostrom 1991, 1997). We think that this criticism, however, should not be stretched so far as to deny the significant role of formal laws at national, regional, and local levels in sustaining and facilitating social cooperation. First of all, formal laws, or the characteristics of a political system broadly understood, can encourage or discourage individuals' efforts to voluntarily solve their collectiveaction problems. Though no authoritarian regime can completely demolish peoples' will and ability to self-organize to deal with the problems they face on a daily basis, whether or not a regime explicitly allows and even encourages those activities makes a big difference for the fate of self-governance. Therefore, a rule of law, a democratic atmosphere, and a well-structured government (if these exist) are valuable social capital for any society.

Formal laws themselves are often major sources of working rules especially when backed with close monitoring and sanctioning by public authorities. The difference between working rules and formal laws depends on the contexts in which 
the working rules operate and the extent that formal laws apply to those contexts. No formal law can completely cover the exigencies arising in daily life, thus working rules may basically involve filling in the lacunae left in general systems of law. However, when the mandates from relevant laws and official regulations are deemed impractical or improper, individuals may devise their own working rules that "assign de facto rights and duties that are contrary to the de jure rights and duties” (E. Ostrom 1992, p. 20).

To provide themselves with working rules to deal with their collective-action problems, individuals need to invest time and resources to devise, revise, monitor, and sanction. Common understanding among the involved individuals regarding what actions and outcomes are expected of themselves and of others is essential for a sustainable set of working rules (Aoki 2007). While the difficulties of sustaining longterm collective action are substantial, the benefits of creating local organizations and selecting locals as leaders who are rewarded for their performance can offset these high costs. Instead of presuming that individuals face an impossible task, we are better advised to assume that it is possible, even though difficult, for those facing severe collective-action problems to overcome them. To do so, they need sufficient local autonomy to invest in the social and physical capital involved in building systems and monitoring performance.

No general set of formal rules exist that guarantee successful development of working rules in all contexts. The rules used by individuals to structure their patterns of relationships may enhance or retard the creation of other forms of social capital and also affect the level and impact of human and physical capital. Rules relate to patterns of activities at several levels including day-to-day operational activities all the way to constitutional activities that create and recreate the general patterns of authority in a 
society. The type of rules that individuals will find productive depends upon the kinds of norms and patterns of reciprocity that already exist. Similarly, patterns of trust and reciprocity will depend to a large extent upon the types of rules that are crafted in any polity.

Self-governing systems in any arena of social interaction tend to be more efficient and stable not because of any magical effects of grassroots participation itself but because of the social capital in the form of effective working rules those systems are more likely to develop and preserve, the networks that the participants have created, and the norms they have adopted. For example, many scholars have found it hard to understand why the "primitive" irrigation systems built by the farmers themselves significantly outperform those that have been improved by the construction of modern, permanent, concrete, and steel headworks, often funded by donors and constructed by professional engineering firms (E. Ostrom 1999).

Many factors contribute to these results, most of them related to the incentives of key participants in the finance, design, construction, operation, and maintenance of differently organized irrigation systems. On farmer-governed irrigation systems, farmers craft their own rules to counteract the perverse incentives that they face given the physical and cultural setting in which they are enmeshed (Joshi et al. 2000). These rules are frequently invisible to project planners when they design new physical systems. In project planning, most effort focuses on how to improve physical capital, such as creating permanent headworks, that affects various aspects of the technical operation of a system. How these variables affect the incentives of participants is rarely explored. Unless the changes in physical infrastructure are undertaken with a consciousness that they will affect the incentives of participants-sometimes in perverse manners - projects intended to do good may generate harm instead. In other 
words, investment in physical capital that does not also include efforts to improve social capital and the fit between social and physical capital hardly guarantees desired consequences (Gibson et al. 2005).

Simply agreeing on an initial set of rules, on the other hand, is rarely enough. Working out exactly what these rules mean in practice takes time. If those learning how to use a set of rules do not trust one another, further investments are needed in extensive monitoring activities (E. Ostrom and Nagendra 2006). Appropriate sanctions for nonconformance must be developed. Conditions under which exceptions to rules can be made without endangering the basic ordering principles must also be discovered and discussed. Conflict over rule interpretation and adjustment will occur, which if no facilities for conflict resolution are available, may destroy the process of building capital before it gets very far. The time it takes to develop a workable set of rules, known to all relevant parties, is always substantial (Dietz et al. 2003).

Part of learning through experience is what happens when things go wrong. In all practical affairs, many things can go wrong. Everyone may not have received the same information about joint objectives, processes to be followed, and how one process feeds into another. Some may do their part while others fail to perform. Some may want to interpret a rule in a way that is harmful to the interests of others. There may not be fair and objective conflict-resolution processes available. Conflict may destroy prior lessons about how to work together and may reinforce prior doubts about the reliability and trustworthiness of some participants.

Thus, social capital is not only created, it can be weakened, destroyed, strengthened, or transformed. Social capital can be characterized as outdated, up-todate, or ahead of its time. It may enhance the outcomes of a few without any impact on others. Or, advantages to the few may come at the expense of others. Alternatively, 
the advantages to a few may also generate positive benefits for others. A system of government based upon military command and use of instruments of force can also destroy other forms of social capital while building its own. 


\section{Notes}

We are deeply appreciative of support that we have received from the National Science Foundation, the Ford Foundation, and the MacArthur Foundation and the fabulous editing by Patty Lezotte.

${ }^{1}$ For several ambitious attempts to formalize the concept of social capital and its effects, see Annen (2002a, 2002b) and Henning (2002).

${ }^{2}$ The following section draws on E. Ostrom and Ahn (2001), but is substantially revised.

${ }^{3}$ Using one's own view of what one would do in a situation has repeatedly been found to be a good predictor of one's expectations about what someone else would do in that situation. In social dilemma situations, those that choose the more cooperative strategies usually have a higher expectation that others will also cooperate than those who do not cooperate (see Orbell et al. 1984; Orbell and Dawes 1991). ${ }^{4}$ Yamagishi's discussion of trust focuses on its relationship with social intelligence; a higher level of social intelligence allows a person to entertain a correspondingly higher level of trust. This appears to consider trust as an individual's disposition. What is not clear in his discussion is whether a person's default expectation of others' trustworthiness also reflects the objective level of trustworthiness of others.

${ }^{5}$ Berman (1983, p. 557) noted in his discussion of the importance of legal systems that the "legal ordering is itself a form of capital." 


\section{References}

Ahn, T. K., Justin Esarey, and John Scholz (2007), 'Reputation and cooperation in voluntary exchange: Comparing local and central institutions’, paper presented at the American Political Science Association meeting, Chicago, IL, 29 August-3 September.

Ahn, T. K., Elinor Ostrom, David Schmidt, Robert Shupp, and James Walker (2001), 'Cooperation in PD games: Fear, greed, and history of play', Public Choice, 106 (1/2), 137-155.

Ahn, T. K., Elinor Ostrom, and James Walker (2003), 'Heterogeneous preferences and collective action', Public Choice, 117 (3-4), 295-314.

Annen, Kurt (2002a), 'Social capital, inclusive networks, and economic performance’, paper presented at the Public Choice Society meeting, San Diego, CA, 22-24 March.

Annen, Kurt (2002b), 'Social norms, communication, and community enforcement', Working paper. St. Louis, MO: Washington University, Department of Economics.

Aoki, Masahiko (2007), 'Endogenizing institutions and institutional change’, Journal of Institutional Economics, 3 (1), 1-31.

Arrow, Kenneth (1972), 'Gifts and exchanges', Philosophy and Public Affairs, 1, $343-362$.

Arrow, Kenneth (1999), 'Observations on social capital’, in Partha Dasgupta and Ismail Serageldin (eds), Social Capital: A Multifaceted Perspective, Washington, DC: The World Bank, pp. 3-5.

Axelrod, Robert (1981), 'The emergence of cooperation among egoists', American Political Science Review, 75 (2), 306-318. 
Axelrod, Robert (1984), The Evolution of Cooperation, New York: Basic Books.

Baker, Mark (2005), The Kuhls of Kangra: Community-Managed Irrigation in the Western Himalaya, Seattle: University of Washington Press.

Becker, Gary S. (1962), 'Investment in human capital: A theoretical analysis’, Journal of Political Economy, 70 (5), 9-49.

Becker, Gary S. (1964), Human Capital, New York: Columbia University Press.

Bentley, A. (1949), The Process of Government, Evanston, IL: Principia Press.

Berman, Harold J. (1983), Law and Revolution: The Formation of the Western Legal Tradition, Cambridge, MA: Harvard University Press.

Blomquist, William (1992), Dividing the Waters: Governing Groundwater in Southern California, San Francisco, CA: ICS Press.

Bolton, Gary and Axel Ockenfels (2000), 'ERC: A theory of equity, reciprocity, and competition’, American Economic Review, 90, 166-93.

Bourdieu, Pierre (1986), 'Forms of capital’, in John G. Richardson (ed), Handbook of Theory and Research for the Sociology of Education, New York: Greenwood Press, pp. 241-58.

Bowles, Samuel (1998), 'Endogenous preferences: The cultural consequences of markets and other economic institutions', Journal of Economic Literature, 36, 75-111.

Bowles, Samuel (2000), 'Individual interactions, group conflicts, and the evolution of preferences’, in Steve Durlauf and Peyton Young (eds), Social Dynamics, Washington, DC: Brookings Institution.

Burt, Ronald S. (1992), Structural Holes: The Social Structure of Competition, Cambridge, MA: Harvard University Press. 
Camerer, Colin F. (2003), Behavioral Game Theory: Experiments in Strategic Interaction, Princeton, NJ: Princeton University Press.

Charness, Gary and Matthew Rabin (2002), 'Understanding social preferences with simple tests', Quarterly Journal of Economics, 117 (3), 817-869.

Clark, Kenneth and Martin Sefton (2001), ‘The sequential prisoner’s dilemma: Evidence on reciprocation', Economic Journal, 111, 51-68.

Coleman, James S. (1988), 'Social capital in the creation of human capital', American Journal of Sociology, 94 (supplement), S95-S120.

Collier, Paul and Jan Willem Gunning (1999), 'Explaining African economic performance', Journal of Economic Literature, 37, 64-111.

Crawford, Sue E. S. and Elinor Ostrom (2005), ‘A grammar of institutions', in Elinor Ostrom (ed), Understanding Institutional Diversity, Princeton, NJ: Princeton University Press, pp. 137-174. Originally published in American Political Science Review, 89 (3) (1995), 582-600.

Dietz, Thomas, Elinor Ostrom, and Paul Stern (2003), 'The struggle to govern the commons', Science, 302 (5652), 1907-1912.

Durlauf, Steven N. (2002), ‘Bowling alone: A review essay’, Journal of Economic Behavior and Organization, 47 (3), 259-274.

Fehr, Ernst and Klaus Schmidt (1999), 'A theory of fairness, competition, and cooperation', Quarterly Journal of Economics, 114, 817-868.

Fine, Ben (2001), Social Capital versus Social Theory: Political Economy and Social Science at the Turn of the Millennium, London: Routledge.

Freitag, M. (2006), 'Bowling the state back in: Political institutions and the creation of social capital', European Journal of Political Research, 45, 123-152. 
Frey, Bruno S. (1994), 'How intrinsic motivation is crowded out and in’, Rationality and Society, 6, 334-352.

Frey, Bruno S. (1997), Not Just for the Money: An Economic Theory of Personal Motivation, Cheltenham, UK: Edward Elgar.

Frey, Bruno S. and Iris Bohnet (1996), ‘Cooperation, communication, and communitarianism: An experimental approach’, Journal of Political Philosophy, 4 (4), 322-336.

Fukuyama, Francis (1995), Trust: The Social Virtues and the Creation of Prosperity, New York: The Free Press.

Fuller, Lon (1981), The Problem of Social Order, Durham, NC: Duke University Press.

Gambetta, Diego (1988), 'Mafia: The price of distrust', in Diego Gambetta (ed), Trust: Making and Breaking Cooperative Relations, London: Basil Blackwell, pp. 158-175.

Gambetta, Diego (2000), 'Can we trust trust?’, in Diego Gambetta (ed), Trust: Making and Breaking Cooperative Relations, Oxford, UK: University of Oxford, Department of Sociology, electronic edition, pp. 213-237.

Gibson, Clark, Krister Andersson, Elinor Ostrom, and Sujai Shivakumar (2005), The Samaritan's Dilemma: The Political Economy of Development Aid, New York: Oxford University Press.

Gintis, Herbert (2000), Game Theory Evolving, Princeton, NJ: Princeton University Press.

Granovetter, Mark (1973), 'The strength of weak ties', American Journal of Sociology, 78, 1360-1380. 
Greif, Avner, Paul Milgrom, and Barry R. Weingast (1994), 'Coordination, commitment, and enforcement: The case of the merchant guild', Journal of Political Economy, 102 (4), 745-776.

Grootaert, Christiaan (1998), 'Social capital, household welfare and poverty in Indonesia’, Social Capital Initiative Working Paper no. 2148, Washington, DC: The World Bank.

Güth, Werner and Hartmut Kliemt (1998), 'The indirect evolutionary approach: Bridging the gap between rationality and adaptation', Rationality and Society, 10 (3), 377-399.

Güth, Werner, Hartmut Kliemt, and Bezalel Peleg (2000), ‘Co-evolution of preferences and information in simple games of trust', German Economic Review, 1 (1), 83-110.

Güth, Werner and Menahem Yaari (1992), ‘An evolutionary approach to explaining reciprocal behavior in a simple strategic game', in Ulrich Witt (ed), Explaining Process and Change: Approaches to Evolutionary Economics, Ann Arbor: University of Michigan Press, 23-34.

Hanifan, L. J. (1920), The Community Center, Boston, MA: Silver, Burdett \& Company.

Hardin, Garrett (1968), 'The tragedy of the commons’, Science, 162, 1243-1248.

Hardin, Russell (2002), Trust and Trustworthiness, New York: Russell Sage Foundation.

Heiner, Ron (2002), 'Robust evolution of contingent-cooperation in pure one-shot prisoners’ dilemmas’, Working paper, Fairfax, VA: James Buchanan Center for Political Economy. 
Henning, Christian H. C. A. (2002), 'On the conception of social capital in the framework of a generalized version of Coleman's linear system of action’, paper presented at the Public Choice Society meeting, San Diego, CA, 22-24 March.

Henrich, Joe (2004), 'Cultural group selection, co-evolutionary processes and largerscale cooperation', Journal of Economic Behavior and Organization, 53 (1), 85-88.

Hoffman, Elizabeth and Gary Libecap (1995), 'The failure of government-sponsored cartels and development of federal farm policy’, Economic Inquiry, 33, 365382.

Jacobs, Jane (1961), The Death and Life of Great American Cities, New York: Random House.

Janssen, Marco (2006), 'Evolution of cooperation when feedback to reputation scores is voluntary', Journal of Artificial Societies and Social Simulation, 9 (1), http://jasss.soc.surrey.ac.uk/9/1/17.html (accessed 12 September 2007).

Joshi, Neeraj, Elinor Ostrom, Ganesh Shivakoti, and Wai Fung Lam (2000), 'Institutional opportunities and constraints in the performance of farmermanaged irrigation systems in Nepal', Asia-Pacific Journal of Rural Development, 10 (2), 67-92.

Kawachi, Ichiro, Bruce P. Kennedy, and Kimberly Lochner (1997), 'Long Live Community: Social Capital as Public Health', The American Prospect, (November/December), 56-59.

Krishna, Anirudh (2002), Active Social Capital: Tracing the Roots of Development and Democracy, New York: Columbia University Press. 
Lachmann, Ludwig M. (1978), Capital and Its Structure, Kansas City, MO: Sheed Andrews and McMeel.

Lake, Ronald La Due and Robert Huckfeldt (1998), 'Social capital, social networks, and political participation’, Political Psychology, 19 (3), 567-584.

Langbein, Laura and Roseana Bess (2002), 'Sports in school: Source of amity or antipathy', Social Science Quarterly, 83, 2, 436-454.

Langbein, Laura and Connie M. Jorstad (2002), 'Productivity in the workplace: Cops, culture, communication, cooperation, and collusion’, Working paper, Washington, DC: School of Public Affairs, American University.

Loury, Glenn (1977), ‘A dynamic theory of racial income differences’, in P. A. Wallace and A. LeMund (eds), Women, Minorities, and Employment Discrimination, Lexington, MA: Lexington Books, pp. 153-188.

Maggi, Giovanni (1999), 'The role of multilateral institutions in international trade cooperation', American Economic Review, 89 (1), 190-214.

Malaga, Ross A. (2001), 'Web-based reputation management system: Problems and suggested solutions', Electronic Commerce Research, 1, 403-417.

Milgrom, Paul R., Douglass C. North, and Barry R. Weingast (1990), 'The role of institutions in the revival of trade: The law merchant, private judges, and the champagne fairs', Economics \& Politics, 2 (1), 1-23.

North, Douglass C. (1990), Institutions, Institutional Change, and Economic Performance, New York: Cambridge University Press.

NRC (National Research Council) (2002), The Drama of the Commons, Committee on the Human Dimensions of Global Change, Elinor Ostrom, Thomas Dietz, Nives Dolšak, Paul Stern, Susan Stonich, and Elke Weber (eds), Washington, DC: National Academy Press. 
Olson, Mancur (1965), The Logic of Collective Action: Public Goods and the Theory of Groups, Cambridge, MA: Harvard University Press.

Orbell, John M., Peregrine Schwartz-Shea, and Randy Simmons (1984), ‘Do cooperators exit more readily than defectors?', American Political Science Review, 78, 147-162.

Orbell, John M. and Robyn M. Dawes (1991), ‘A ‘cognitive miser’ theory of cooperators’ advantage’, American Political Science Review, 85, 515-528.

Ostrom, Elinor (1992), Crafting Institutions for Self-Governing Irrigation Systems, San Francisco, CA: ICS Press.

Ostrom, Elinor (1998), 'A behavioral approach to the rational choice theory of collective action', American Political Science Review, 92 (1), 1-22.

Ostrom, Elinor (1999), 'Social capital: A fad or a fundamental concept', in Partha Dasgupta and Ismail Serageldin (eds), Social Capital: A Multifaceted Perspective, Washington, DC: The World Bank, pp. 172-214.

Ostrom, Elinor (2005), Understanding Institutional Diversity, Princeton, NJ: Princeton University Press.

Ostrom, Elinor and T. K. Ahn (2001), 'A social science perspective on social capital’, report commissioned by the Enquete Commission of the German Federal Government.

Ostrom, Elinor, Roy Gardner, and James Walker (1994), Rules, Games, and Common-Pool Resources, Ann Arbor: University of Michigan Press.

Ostrom, Elinor and Harini Nagendra (2006), ‘'Insights on linking forests, trees, and people from the air, on the ground, and in the laboratory', PNAS, 103 (51), 19224-19231. 
Ostrom, Elinor and James Walker (eds) (2003), Trust and Reciprocity: Interdisciplinary Lessons from Experimental Research, New York: Russell Sage Foundation.

Ostrom, Vincent (1991), The Meaning of American Federalism: Constituting a SelfGoverning Society, San Francisco, CA: ICS Press.

Ostrom, Vincent (1997), The Meaning of Democracy and the Vulnerability of Democracies: A Response to Tocqueville’s Challenge, Ann Arbor: University of Michigan Press.

Putnam, Robert, with Robert Leonardi and Raffaella Nanetti (1993), Making Democracy Work, Princeton, NJ: Princeton University Press.

Rabin, Matthew (1993), 'Incorporating fairness into game theory and economics’, American Economic Review, 83 (5), 1281-1302.

Resnick, Paul, Zeckhauser, Richard, Swanson, John, and Kate Lockwood (2006), 'The value of reputation on eBay: A controlled experiment', Experimental Economics, 9 (2), 79-101.

Richerson, Peter J. and Robert Boyd (2005), Not by Genes Alone: How Culture Transformed Human Evolution, Chicago: University of Chicago Press.

Schultz, Theodore (1961), 'Investment in human capital', American Economic Review $51,1-17$.

Solow, Robert M. (1999), 'Notes on social capital and economic performance', in Partha Dasgupta and Ismail Serageldin (eds), Social Capital: A Multifaceted Perspective, Washington, DC: The World Bank, pp. 6-9.

Standifird, Stephen S. (2001), 'Reputation and E-commerce: eBay auctions and the asymmetrical impact of positive and negative ratings', Journal of Management, 27, 279-295. 
Svendsen, Gert Tinggaard and Gunnar Lind Haase Svendsen (2004), The Creation and Destruction of Social Capital: Entrepreneurship, Co-operative Movements and Institutions, Cheltenham, UK: Edward Elgar.

Taylor, Michael (1982), Community, Anarchy, and Liberty, Cambridge: Cambridge University Press.

Tocqueville, Alexis de ([1840] 1945), Democracy in America, New York: Alfred A. Knopf.

Torsvik, Gaute (2000), 'Social capital and economic development', Rationality and Society, 12 (4), 451-476.

Trivers, R. L. (1971), ‘The evolution of reciprocal altruism', Quarterly Review of Biology, 46, 35-57.

Truman, D. B. (1958), The Governmental Process, New York: Knopf.

Yamagishi, Toshio (2001), ‘Trust as a form of social intelligence’, in Karen Cook (ed), Trust in Society, New York: Russell Sage Foundation, pp. 121-147. Yamagishi, Toshio, Masako Kikushi, and Motoko Kosugi (1999), 'Trust, gullibility, and social intelligence', Asian Journal of Social Psychology, 2 (1), 145-161. 


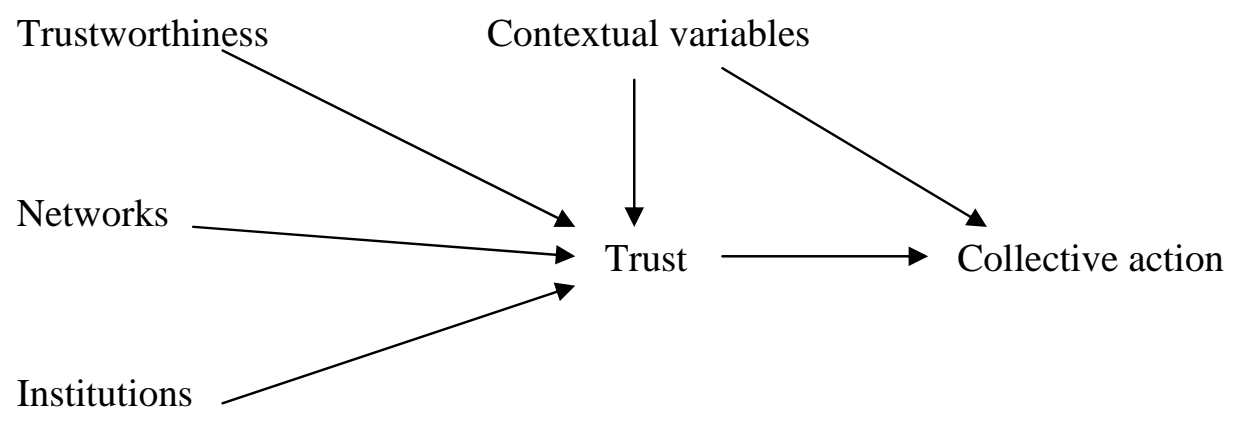

Figure 1. Trust, forms of social capital, and their linkage to achieving collective action 
Table 1. Citations in Web of Science on social capital*

\begin{tabular}{cc}
\hline Year & Number of citations \\
\hline 1991 & 2 \\
1992 & 3 \\
1993 & 15 \\
1994 & 12 \\
1995 & 27 \\
1996 & 37 \\
1997 & 61 \\
1998 & 102 \\
1999 & 127 \\
2000 & 150 \\
2001 & 220 \\
2002 & 251 \\
2003 & 291 \\
2004 & 300 \\
2005 & 403 \\
2006 & 443 \\
& \\
\hline Thanks to Charlotte Hess for doing this search.
\end{tabular}

